\title{
STUDENTŲ FIZINĖS SVEIKATOS TAUSOJIMO, GERINIMO, PULSO BEI KRAUJOSPŪDŽIO KONTROLĖS IR MANKŠTINIMOSI LAISVALAIKIU SĄSAJOS ANALIZE்
}

\author{
Algirdas Muliarčikas ${ }^{1}$, Robertas Veršinskas ${ }^{1}$, Aleksas Stanislovaitis ${ }^{2}$ \\ Mykolo Romerio universitetas ${ }^{1}$, Lietuvos kūno kultūros akademija ${ }^{2}$, Kaunas, Lietuva
}

\begin{abstract}
Algirdas Muliarčikas. Docentas socialinių mokslų daktaras. Mykolo Romerio universiteto Kauno policijos fakulteto Specialaus fizinio rengimo katedros vedėjas. Mokslinių tyrimų kryptis — sociopedagoginių, psichologinių bei fizinių savybių lavinimo valdymo aspektai asmenybės ir specialisto ugdymo procese.
\end{abstract}

\section{SANTRAUKA}

Tyrimo tikslas - nustatyti Kauno universitetinio tipo aukštuju mokyklu studentu fizinès sveikatos vertinimo, gerinimo, pulso ir kraujospüdžio kontrolès, populiariausiu sveikatinimo priemoniu pasirinkimo sasaja su mankštinimusi laisvalaikiu.

Straipsnyje pateikiami Kauno aukštuju mokyklu pirmakursiu anketinès apklausos duomenys, nusakantys studentu fizinès sveikatos büklę, vertinima, paprasčiausius jos būsenos kontrolès büdus ir mankštinimosi laisvalaikiu reikšmę sveikatinimo procese. Anonimiškai apklausti 992 pirmo kurso studentai, studijave šešiose Kauno aukštosiose mokyklose: KTU, KMU, VDU, LVA, LŽUUU, LTU (dabar MRU). Anketa aprobuota. Buvo atliktas bandomasis tyrimas, nustatytas anketos stabilumas.

Dauguma apklaustu studentu rüpinosi savo sveikata (85\%). Didesnès respondentu dalies (52\%) sveikatos büklè patenkinama. Iš visu apklaustuju mažiausia LŽUŪ studentu dalis (33\%) savo sveikatq ìvertino gerai $(p<0,05)$. Daugiausia besilankančiu pas gydytojus dažniau nei 3 kartus per metus buvo KTU (24\%), mažiausia - KMU ir LTU (po 13\%) pirmakursiu. 70\% apklaustuju neskaičiavo savo pulso dažnio, o 59\% nežinojo jo reikšmiu. 27\% pirmakursiu neturëjo supratimo apie kraujospūdžio informatyvumo reikšmę. Daugiausia LŽŨU (58\%), o mažiausiai KMU studentu (39\%) nežinojo savo kraujospüdžio reikšmiu $(p<0,01)$. Dauguma respondentu mané, kad adekvatus fizinis krūvis yra viena iš svarbesniu antsvorio mažinimo (50\%) ir sveikatos gerinimo (26\%) priemoniu. Studentai išskyré tris svarbesnes priemones, padedančias dienq büti žvalesniems: kavos gèrima ryte (21\%), apsiliejimq šaltu vandeniu (19\%) ir fizinę mankšta (18\%). Kauno aukštuju mokyklu studentai susidare pozityviq samprata apie pagrindinius fizinès sveikatos gerinimo büdus, tačiau palyginti maža visu respondentu dalis turëjo informacijos apie pulsa (41\%) ir kraujospūdì (51\%), kaip paprasčiausius žmogaus fizinès sveikatos būklès kontrolés bei laisvalaikio fizinio aktyvumo proceso valdymo rodiklius.

Raktažodžiai: fizinè sveikata, žinios apie pulsq ir kraujospūdì, organizmo sveikatinimo priemonès, fizinis aktyvumas laisvalaikiu.

\section{IVADAS}

$\mathrm{M}$ ankštinimasis laisvalaikiu, norint igyti ir palaikyti gerą fizinio pasirengimo bei svarbiausių organizmo sistemų funkcionavimo lygi, ganėtinai sudėtingas procesas.

Subjektyvus fizinès sveikatos būklès vertinimas, priežiūra (Grabauskas ir kt., 1997; Stepaitienè, 1999), fiziologinių rodiklių kitimo kontrolè, aktyvaus gyvenimo būdo pasirinkimas (Poderys, 2000; Petrauskas, 2004; Skernevičius ir kt.,
2004) ir neigiamų jaunimo ipročiu išvengimas (Petkevičienè ir kt., 2002; Goštautas, Šeibokaitè, 2003) - būtu vienos iš aktualesnių sąlygu, teigiamai veikiančių fizinès sveikatos tausojimo procesą. Būtina pažymèti, kad pulsometrija, kaip kontrolès metodas, dažnai naudojamas fiziškai aktyvioje veikloje ir kasdieniame gyvenime, nes širdies tvinksnių dažni nesudètinga registruoti. Duomenys apie pulso rodiklių pokyčius sutei- 
kia daug svarbios informacijos apie viso žmogaus organizmo būsena, jo reakciją i fizini krūvi (Баевский, 1986; Тхоревский, 2001; Skernevičius ir kt., 2004). Kiti informatyvūs ir reikšmingi rodikliai, padedantys kontroliuoti ir valdyti mankštinimosi procesą — fizinio krūvio bei atsigavimo priemonių taikymą - yra sistolinio ir diastolinio kraujospūdžio reikšmès (Тхоревский, 2001; Buliuolis ir kt., 2003). Taigi, siekiant geidžiamos fizinès sveikatos - optimalaus žmogaus kūno sistemų funkcionavimo lygio, būtinos žinios apie žmogaus fiziologijos, fiziškai aktyvaus gyvenimo būdo (mankštinimosi) ypatumus bei kontrolès, valdymo priemones ir metodus (Poderys, 2000; Skernevičius ir kt., 2004). Deja, tokių žinių pakankamai turi ne visi abiturientai (Muliarčikas, 2003). Studentu sveikatos bei fizinio aktyvumo lygis nèra pakankamas ir jis ne gerèja (Juškelienè ir kt., 2003; Vaščila, 2003; Astrauskienè ir kt., 2005). Tyrèjų (Tamošauskas, 2000, 2004; Petkevičienè ir kt., 2002; Muliarčikas, 2003; Vaščila, 2003; Astrauskienė ir kt., 2005), analizavusių pirmo kurso studentų sveikatingumo rodiklius, fizinès saviugdos aspektus, fizinio aktyvumo ir žalingu ipročių ryšio ypatumus, turimas žinias apie sveikatos stiprinima, išvados nenuteikia labai gerai.

Šiuo tyrimu norèjome išnagrinèti tokius klausimus: kaip pirmakursiai vertina, rūpinasi savo fizinès sveikatos būkle; ar kontroliuoja ją stebėdami paprasčiausius fiziologinius rodiklius (pulso dažni ir kraujospūdi); kokią reikšmę jie teikia fiziniam aktyvumui laisvalaikiu, kaip sveikatinimo priemonei; ar užtenka apklaustiems studentams paprasčiausių žinių, kad galètų savarankiškai mankštintis nekeldami pavojaus fizinei sveikatai?

Tikslas - nustatyti Kauno universitetinio tipo aukštujų mokyklų studentų fizinès sveikatos vertinimo, gerinimo, pulso ir kraujospūdžio kontrolès, populiariausių sveikatinimo priemonių pasirinkimo sąsają su mankštinimusi laisvalaikiu. Manome, kad tyrimo rezultatai padès nustatyti studentų fizinio aktyvumo laisvalaikiu neigiamus ir teigiamus veiksnius.

\section{TYRIMO METODAI}

Tyrimas atliktas Kauno aukštosiose mokyklose, kuriose yra Kūno kultūros katedros. Anketa parengta Lietuvos kūno kultūros akademijoje konsultuojantis su Socialinių ir humanitarinių mokslų katedros, Kūno kultūros ir sporto socialiniu problemų tyrimų laboratorijos darbuotojais. Tai uždara, anoniminė anketa. Anketos patikimumui patikrinti atliktas bandomasis tyrimas. Nustatytas anketos stabilumas - mènesio laikotarpiu du kartus apklausėme tuos pačius 60 Lietuvos kūno kultūros akademijos studentų, palyginome atsakymus ir koregavome anketą. Ją sudare 38 klausimai, suskirstyti į kelias grupes: pirma — pradinè informacija apie respondentą (5 klausimai: lytis, amžius, ūgis, svoris, iš kur atvyko); antra — apie fizinès sveikatos vertinimo ir tausojimo ypatumus (5 klausimai); trečia — informacijos gavimo apie metodinius mankštinimosi ypatumus būdai (5 klausimai); ketvirta - apie fizinị lavinimąsi laisvalaikiu ir ji veikiančias aplinkybes (10 klausimu); penkta — apie fiziologinių rodiklių (pulso, kraujospūdžio) kontrolès ypatumus (8 klausimai); šešta - sveikatinimo aspektai (5 klausimai apie fizinio aktyvumo ir kitu priemonių poveiki fizinei sveikatai). Šiame straipsnyje analizuojami studentų atsakymai, susiję su antra, penkta ir šešta anketos klausimų grupe.

Tyrimo metu vykdyta Kauno technologijos (KTU), Vytauto Didžiojo (VDU), Kauno medicinos (KMU), Lietuvos teisès (dabar Mykolo Romerio universiteto - MRU, Kauno policijos fakulteto - KPF), Lietuvos žemės ūkio (LŽŪU) universitetų ir Lietuvos veterinarijos akademijos (LVA) I kurso studentu anoniminè anketinè apklausa. Buvo išdalyta 1100 anketų ir paaiškinta, kaip jas pildyti. Apklausą organizuoti ir vykdyti, praejjus $2-3$ mènesiams nuo studiju pradžios (spalio-lapkričio mėnesiais), padejjo aukštuju mokyklų Kūno kultūros katedrų dėstytojai. Pratybų metu, neatsižvelgiant ị mokslo krypti, o tik i pirmakursių skaičių konkrečiame universitete, atsitiktinès atrankos būdu kiekvienoje aukštojoje mokykloje buvo apklausta nuo 140 iki 220 respondentų. Anketas grąžino 992 aukštujų mokyklų studentai. Tai sudarè $20 \%$ visų studentu, kurie studijavo minètų universitetų I kurso dieniniuose skyriuose. Anketinès apklausos duomenų analizè atlikta naudojant SPSS 8.0. for Windows programą. Gautų rezultatų, tiriamų skirstinių homogeniškumui įvertinti naudojome $\chi^{2}$ (chi kvadrato) kriterijų. Skirstinius vertinome kaip heterogeniškus, jei reikšmingumo lygmuo buvo mažesnis nei 0,05 .

\section{REZULTATAI}

Fizinès sveikatos būklẻ ir priežiūra. Dauguma (85\% Kauno universitetuose studijuojančiu studentų) teigè, kad rūpinasi savo fizine sveikata. 
Pagal anketinės apklausos rezultatus, lyginant juos su kitu universitetų studentų, mažiausiai savo sveikata rūpinasi studijuojantys VDU (75\%) $(\mathrm{p}<0,001)$.

Savo fizinès sveikatos būklę patenkinamai vertino maždaug pusė apklaustų aukštujų mokyklu studentų (52\%). 41\% pirmakursių gerai vertino savo sveikata, o 7\% - neigiamai. Reikšmingai didesnè dalis LTU (46\%) ir KMU (48\%) $(\mathrm{p}<0,05)$ apklaustuju, lyginant su KTU (36\%) ir LŽŪU (33\%) studentais, savo sveikatą ivertino kaip gerą. Didžiausia LŽŪU (60\%) respondentų dalis, lyginant su KMU (46\%), VDU (48\%) ir LTU (49\%) ( $\mathrm{p}<0,05)$, teigè, kad jų sveikatos būklè patenkinama. Daugiau kaip pusė (58\%) apklaustų studentu pas gydytojus lankèsi $1-2$ kartus ( $\mathrm{p}<0,001)$, $18 \%$ - dažniau nei po 3 kartus, o 24\% - rečiau nei kartą per metus. Lyginant su KTU (19\%) ( $<<0,05$ ), daugiausia respondentu, teigiančių kad medicinos istaigose lankèsi rečiau nei kartą per metus, buvo iš KMU ir LŽŪU (po 29\%). Reikšmingai daugiau $(\mathrm{p}<0,05)$ apklaustuju iš KTU (24\%) nei iš KMU, LŽŪU (po 13\%) ir LTU (MRU KPF) (14\%) lankèsi pas gydytojus dèl sveikatos problemų dažniau nei 3 kartus per metus.

Pulso dažnio ir kraujospūdžio kontrolè. $68 \%$ respondentų nematavo savo pulso dažnio, o apie 4\% jų teige, kad nemoka to daryti. Mažiausiai nemokančiu skaičiuoti pulso dydžio studijavo KMU (1\%) (p < 0,05), o daugiausia, lyginant su KMU, buvo KTU, LVA ir LTU (MRU KPF) (po $6 \%)(\mathrm{p}<0,01)$. Didžiausia KMU (41\%) respondentų dalis, lyginant su KTU (29\%), LVA (19\%), LŽŪU (18\%) ir LTU (21\%) (p < 0,05), registravo savo pulso reikšmes.

$59 \%$ visų respondentų nežinojo, kokios jų pulso reikšmès. Lyginant su kitu aukštujų mokyklų apklaustais studentais, mažiausia dalis respondentų, nežinančių savo pulso reikšmių, buvo KTU - 22\%, didžiausia - LŽŪU (81\%) ir LVA (79\%) (1 pav.).

$65 \%$ visų apklaustų pirmakursių mano, kad kraujospūdis rodo fizinès sveikatos būklę ( $\mathrm{p}<0,001)$, $7 \%$ - ne, o 27\% neturejjo nuomonès šiuo klausimu. Atskirų apklaustų akademinių bendruomenių grupių respondentų nuomonè dèl kraujospūdžio rodiklių informatyvumo statistiškai reikšmingai nesiskyrè. 58\% ( $<$ 0,001) apklaustų Kauno aukštujų mokyklų studentų nematavo kraujospūdžio. Didžiausia dalis respondentu, matavusių kraujospūdi, buvo KMU (48\%). Lyginant su KMU respondentų atsakymais, statistiškai reikšmingai mažiau $(p<0,05)$ matavusių kraujospūdi studijavo LŽŪU (36\%) ir LTU (MRU KPF) (36\%). Savo kraujospūdžio reikšmes žinojo pusė apklaustujų (51\%). Daugiausia studentų, žinančių savo sistolinio ir diastolinio kraujospūdžio reikšmes, studijavo KMU - 61\% ir kur kas mažiau (p < 0,01) — LVA (45\%), LŽŪU (42\%) ir LTU (MRU KPF) (47\%). 54\% respondentu̧, matuojančiu kraujospūdi, atsake, kad tai daro kartą per metus ( $\mathrm{p}<0,001), 30 \%$ — kartą per mènesi, o $10 \%$ - kartą per savaitę. Lyginant su kitu aukštujų mokyklų studentu atsakymais, mažiausiai kartą per savaitę (3\%) ir kartą per mènesi (17\%) $(\mathrm{p}<0,05)$ matuojančių kraujospūdị studijavo LTU (MRU KPF). Reikšmingai didesnè VDU (24\%) ( $<<0,01)$ nei kitu studentu dalis teigè, kad kraujospūdį matavo kartą per savaitę ar kartą per mènesi (44\%) (p < 0,01). 53\% visų respondentų kraujospūdžio nematavo, nes gerai jautėsi, 31\% neturejo sąlygų to daryti ir $16 \%$ nematè būtinybès. Kad gerai jautėsi, atsakè didžiausia apklaustų LTU (MRU KPF) studentu dalis - 69\% ( $<0,001-$ KTU (40\%), LVA (46\%), LŽUŪ (41\%) respondentų atžvilgiu). Dèl to kraujospūdžio nematavo, kad gerai jautėsi, ir 62\% KMU bei 60\% VDU studentų. Kad nėra sąlygų matuoti kraujospūdžio, iš visų aukštuju mokyklų teigè didžiausia KTU studentų dalis (45\%, $\mathrm{p}<0,01$ ), lyginant su KMU (30\%), VDU (26\%), LŽUŪ (33\%), LTU (MRU KPF) (17\%).

Fizinio aktyvumo ir kitų sveikatinimo priemonių pasirinkimo santykis. I klausimą apie priemonių pasirinkimą norint atsikratyti antsvorio visi respondentai iš kelių pirmenybę teike šioms: fiziniam aktyvumui (50\%); suderintai mitybai (36\%); ivairioms dietoms (5\%). Beveik visų universitetu studentu pasirinkimo variantu — fizinio aktyvumo, suderintos mitybos ir įvairių dietu — santykio skirtumas buvo statistiškai reikšmingas $(p<0,01)$.

Visi anketinejje apklausoje dalyvavę studentai, norėdami pagerinti sveikata, pirmiausia rinktusi dozuoto krūvio fizinius pratimus $(26 \%-\mathrm{p}<0,001$, lyginant su kitų imčių skirstiniais). Analizuojant kitus aktualesnius pasirinkimus, sudètinga išskirti prioritetus, nes vitaminų vartojimą ir grūdinimosi procedūras paminejjo po $16 \%$, o neigiamu ipročiu atsikratymą $-15 \%$ visų studentų. Dèl dozuoto krūvio fizinių pratimų pasirinkimo visų aukštụjų mokyklų studentų nuomonè sutapo. Antrai priemonei (vitaminams) didesni dèmesį skyrè LTU (MRU KPF) $(23 \%, p<0,05)$ nei KMU $(13 \%)$ studentai. Santykiškai didesnė KMU (19\%) nei LTU (MRU KPF) $(12 \%$; p < 0,05) studentų dalis kreipé dèmesi i grūdinimosi procedūras ir į neigiamų ipročių atsi- 

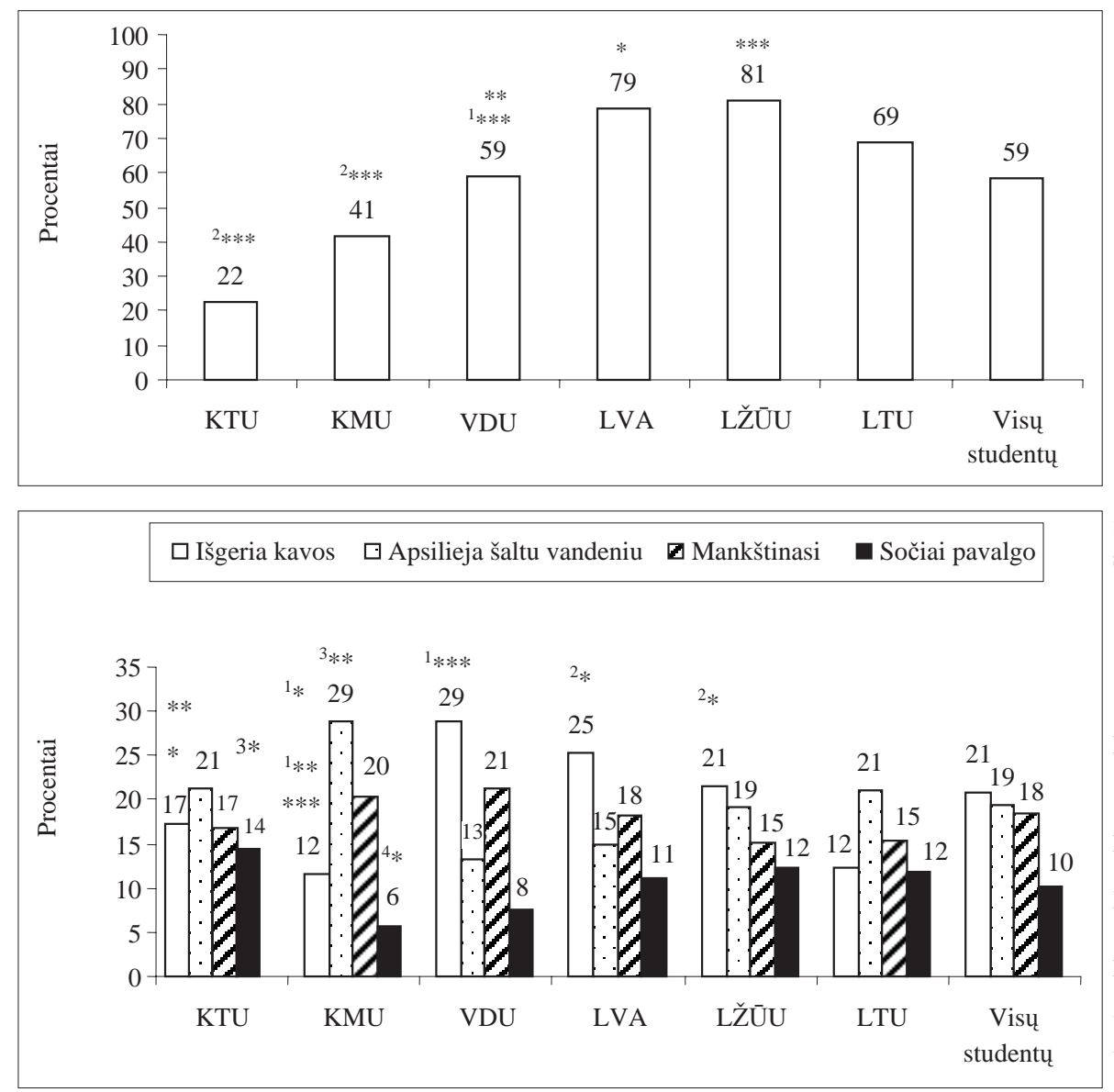

1 pav. Savo pulso reikšmių nežinantys studentai (\%)

Pastaba. Reikšmingas skirtumas: * $-\mathrm{p}<0,05$, lyginant su LTU; ** — p $<0,001$ - su LTU; $* * *-\mathrm{p}<0,001-\mathrm{su} \mathrm{LTU}$ $1 * * *$ - $p<0,001$ - su LVA ir LŽŨU; ${ }^{2} * * *-\mathrm{p}<0,001$ - su visų kitų universitetų studentų at-

2 pav. Priemonės, kurias naudodami studentai būna žvalesni

Pastaba. Reikšmingas skirtumas: * - p $<0,05$, lyginant su LVA; ${ }^{1 *}$ - $\mathrm{p}<0,05$ - su LŽŪU; ${ }^{2 *}-$ $\mathrm{p}<0,05$ - su LTU; ${ }^{3 *}$ - $\mathrm{p}<0,05-$ su KMU; ${ }^{4 *}$ - p $<0,05$ - su LŽŪU, LTU; ** - p < 0,01 - su VDU; ${ }^{1 * *}-\mathrm{p}<0,01$ - su LVA; ${ }^{2 * *}$ $\mathrm{p}<0,01$ - su LTU; ${ }^{3 * *}$ - $\mathrm{p}<0,01-$ su VDU, LVA; *** — p $<0,001-$ su VDU; ${ }^{1 * * *}$ — $\mathrm{p}<0,001$ - su LTU universiteto studentu atsakymais. kratymo veiksni (atitinkamai 11 ir 19\%; p < 0,05). Kitų universitetų studentų nuomonè išskiriant prioritetus santykiškai sutapo.

Statistiškai reikšmingai dominuojančios nuomonès apie vienintelę priemonę, kuri teigiamai veiktų studentų dienos darbingumą, nebuvo (2 pav.). Apibendrinant visus apklausos rezultatus, galima teigti, kad studentai ryte mielai išgertu kavos (21\%), pasimankštintų (18\%) ir apsilietų šaltu vandeniu (19\%).

Iš pateiktų 9 veiksnių, galimai veikiančių darbingumą, ketvirtu pagal aktualumą buvo pasirinktas abstraktusis — „sočiai pavalgyti“ (10\%). Skirtingu aukštujų mokyklų studentai prioritetus skyrè ne tiems patiems veiksniams. VDU, LVA ir LŽŪU ( $p<0,01$, lyginant su KTU, KMU ir LTU (MRU KPF)) studentai prioritetus skyrè rytinès kavos gérimui. KTU, KMU ( $p<0,01$, lyginant su VDU ir LVA, o p < 0,05 — su LŽŪU) studentai kaip efektyvesnę žvalinimo priemonę i̇vardija apsiliejimą šaltu vandeniu. LTU (MRU KPF), LVA, VDU, KMU ir santykiškai KTU respondentai mankštinimąsi įvardijo kaip antrą pagal svarbą dienos darbingumą lemiantị veiksnị. Reikšmingai skyrèsi $(\mathrm{p}<0,05)$ KTU ir KMU respondentų atsakymai sotaus pavalgymo atžvilgiu.
Studentų manymu, „Lietuvos žmonių fizinės sveikatos gerinimo procesą“ turètų pradèti vykdyti: 1) pats asmuo; 2) vyriausybinès institucijos; 3) klubai; 4) visuomeninės organizacijos. Ši variantą pasirinko 50\% visų apklaustų studentų. Kitus variantus rinkosi nuo 12 iki 16\% respondentų.

\section{REZULTATŲ APTARIMAS}

Daugiau kaip trys ketvirtadaliai (85\%) apklaustų Kauno aukštujų mokyklų studentų rūpinasi savo sveikata, jos būkle. Panašūs duomenys gauti vykdant apklausą 2004 m. (Astrauskienė ir kt., 2005). Vienų autorių tyrinejjusių studentu fizinès sveikatos būklès kitimą studiju perspektyvos aspektu, teigimu, studentų sveikata studijų proceso metu turi ryškią tendenciją blogèti (Armonienè, 1994). Kitų (Grinienè, 2005) duomenimis, net $60,3 \%$ trečiakursių laikè save sveikais, t. y. jų sveikata turèjo būti puiki, pakankamai gera ar patenkinama. 2000 m. apklausti Kauno universitetų pirmakursiai (Petrauskas, 2004) savo sveikatos būklę pagal vertinimo kategorijas „gera“ ir „bloga“ ivertino geriau nei mūsų respondentai. Pastarųu, vertinančių fizinę sveikatą kaip gerą, dalis mažesnè beveik 20\%. Lyginant duomenis su 
Vilniaus Gedimino technikos universiteto (VGTU) studentų apklausos atsakymais (Tamošauskas, 2004), mūsų tirtujų vertinančių sveikatą kaip gerą (41\%), dalis mažesnè beveik 10\%. Nustatyta, kad geresnè sveikata būna tų studentų, kurie lengviau integruojasi socialiai (Grinienè, 2005). Be to, lyginant Pabaltijo bei kitų pasaulio šalių bendraamžių (Astrom, Rise, 2001; Zaborskis, Makari 2001) ir Lietuvos jaunimo, aukštesniujų klasių moksleivių nuomones, mūsų tautiečiai savo sveikatos būklę linkę vertinti prasčiau. Norint objektyviai įvertinti sveikata, reikètu bent kartą per metus apsilankyti pas gydytoją profilaktiškai ir nepasitenkinti subjektyviais savijautos pojūčiais. Galima teigti, kad vienas iš sudètinių sveikatos būklę lemiančių veiksnių turètų būti - lankymasis pas gydytoją prevencijos tikslais (Petrauskas, 2004). Panašaus ar truputị vyresnio amžiaus Lietuvos gyventoju apklausos duomenis (Grabauskas ir kt., 1997) lyginant su mūsų respondentų atsakymais, beveik $12 \%$ (mažesnè I kurso studentų dalis) per metus nè karto nesilankè pas gydytoją, 3 ir daugiau kartų pas gydytojus lankèsi beveik 4\% (mažesnè), o $1-2$ kartus per metus - apie 15\% (didesnè studentų dalis). Tačiau 20-24 metų amžiaus Lietuvos gyventojai ir pirmo kurso studentai, vertinę fizinės sveikatos būklę pagal kriterijus „gera“, „patenkinama“, „bloga“, pasiskirstè panašiomis dalimis. Mūsų duomenys apie studentų vizitus pas gydytojus skiriasi ir nuo VGTU studentų atsakymų (Tamošauskas, 2004), o kad fizinès sveikatos būklè gera, teigè $10 \%$ (didesnè VGTU studentu dalis), kad patenkinama - 10\% (didesnè mūsų tirtų respondentų dalis).

Du trečdaliai Lietuvos studentų savo kūno kultūros disciplinos (fizinio krūvio ir organizmo reakcijos i ji kontrolès) žinias vertina patenkinamai ir tik trečdalis pirmakursių suvokia sistemingu fizinių pratybų, savianalizès ir savikontrolès reikšmę (Tamošauskas, 2000; Muliarčikas, 2003). Studijų kryptis veikia studijuojančiuju žinias daugiau informacijos apie sveikatos stiprinimą turi KMU nei KTU studentès (Astrauskienè ir kt., 2005). Gautą informaciją apie informatyviu fiziologinių rodiklių naudojimą organizmo būklès kontrolei priešpastačius teiginiui, kad dauguma studentų tobulinimosi procese prioritetus skiria fiziniam lavinimuisi laisvalaikiu, bet neskiria pakankamai dėmesio savikontrolei (Tamošauskas, 2000), tenka suabejoti tokių mankštų saugumu ir paveikumu. Problema darosi dar aktualesnè dèl silpno studentų širdies ir kraujagyslių siste- mos (ŠKS) funkcinio pajègumo, nepakankamo fizinio aktyvumo, prastėjančio bendro funkcinio pasirengimo ir nemažų studijų krūvių aukštosiose mokyklose (Tamošauskas, 2000; Petkevičienè ir kt., 2002; Astrauskienė ir kt., 2005). 2002 m. $30 \%$ merginu ir 16\% vaikinu, istojusių i LŽŪU, turèjo aukštą arterini kraujospūdị, ir tai rodo, kad studentams būtina kontroliuoti kraujospūdi ir koreguoti fizini krūvị (Vaščila, 2003). Tikètina, kad rečiau nei kartą per metus kraujospūdi matavę ar visai jo nematavę $(45 \%-1994 \mathrm{~m}$. ir 46\% - 2004 m.) apklausti 20-24 metų Lietuvos gyventojai nežinojo savo kraujospūdžio reikšmių (Grabauskas ir kt., 1997, 2005). Atlikto tyrimo duomenys apie kraujospūdžio matavimą ir jo reikšmių žinojimą beveik nesiskiria nuo kitų tyrejjų gautų rezultatų. Žinant, kad fizinis aktyvumas yra viena iš pagrindinių sveikatinimo priemonių ir kad fiziškai aktyvūs studentai labiau rūpinasi sveikata ir teigiamiau ją vertina (Petkevičienè ir kt., 2002; Juškelienė ir kt., 2003; Muliarčikas, 2003; Tamošauskas, 2004), savikontrolè čia ypač svarbi. Visgi apklausos duomenys, rodantys, kad 61,1\% merginu ir 66,2\% I kurso LŽŪU vaikinų savarankiškai besimankštindami nesinaudodavo metodine literatūra (Vaščila ir kt., 2005), verčia suabejoti mankštos paveikumu ir saugumu. Kitas pagal svarbą sveikatos būklei studentų ìvardytas veiksnys - vitaminų vartojimas. Tai prasmingas studentų pasirinkimas, nes Lietuvos ir kitų šalių tyrëjai (Tavelli et al., 1998; Petrauskas, 2004) ypač akcentuoja vitaminingo maisto vartojimo naudą. Neigiamu ipročiu atsisakymas — dar vienas veiksnys, svarbus gerinant sveikata. Vis daugiau aukštesnių klasių moksleiviu žemesnių kursų studentu̧, ypač merginu, pradeda rūkyti ir didesnè dalis turinčiujų neigiamų ipročiu deklaruoja apie pablogèjusią savo sveikatos būklę (Varatinskienė, 1993; Soldz et al., 2000; Goštautas, Šeibokaitė, 2003). Tik apie 50\% baigiamujų klasių moksleivių prieš isstodami i LŽŪU nerūkè (Vaščila, 2003), o $33 \%$ apklaustu KTU ir 13\% KMU pirmo kurso studenčių turèjo neigiamų ipročių (Astrauskienè ir kt., 2005). Pagal 20-24 metu amžiaus Lietuvos gyventojų apklausos duomenis rūkančių buvo apie 68\% (Grabauskas ir kt., 2005). Mūsų duomenimis, pirmakursių, turinčių žalingų ịpročių, dalis pastebimai mažesnè nei teigia kiti tyrejjai.

Kavą vartoja nemaža 20-24 metų amžiaus Lietuvos gyventojų dalis (64,3\%) (Grabauskas ir kt., 2005). Lyginant su šiais duomenimis, kur kas mažesnè mūsų apklaustų studentų dalis vartojo šị 
gėrimą kaip žvalinimo priemonę. Tikètina, kad dalis studentų, netureddami pakankamai metodiniu žiniu apie fizinès mankštos atlikimą ir naudą (Tamošauskas, 2000; Muliarčikas, 2003), mėgino ją daryti ir galiausiai, negavę geidžiamo efekto, pasirinko kavą. Galbūt dèl to visi mūsų apklausti pirmakursiai mankštos poveiki dienos darbingumui paminėjo tik trečiu pagal reikšmingumą. Šios minties negalima priimti vienareikšmiškai, nes atskirų aukštujų mokyklų respondentai iš dalies turejjo skirtingus prioritetus. Studentu požiūris i fizini aktyvumą laisvalaikiu yra pakankamai teigiamas - 53,7\% VGTU studentu, baigusiu privalomo fizinio ugdymo dalyko kursa, norètu mankštintis savarankiškai. Gali būti, kad kavos ar vandens apsiliejimo (grūdinimosi vandeniu) veiksnių pirmenybę lėmè jų stimuliuojamasis poveikis, laiko stygius ir kitos aplinkybès (Jègeris, 1987; Tamošauskas, 2000; Muliarčikas, 2003). Nors minètos priemonès, studentu teigimu, padedančios būti energingesniems, vardijamos tam tikru eiliškumu, pasirinkimo skirstiniai buvo panašūs. Manome, kad susidariusią situaciją reikètų taisyti keičiant sveikos gyvensenos nuostatu formavimo programos psichologinius, metodinius ir struktūrinius aspektus.

\section{IŠVADOS}

1. Dauguma Kauno universitetų pirmo kurso studentų rūpinasi savo fizine sveikata, ją vertina patenkinamai ir pas gydytojus lankosi $1-2$ kartus per metus. Skirtingų aukštujų mokyklų respondentų fizinès sveikatos vertinimo kategorijos reikšmingai skiriasi.

2. Pirmo kurso studentai nepakankamai domisi savo pulso dažnio ir kraujospūdžio reikšmèmis. Bendrojo lavinimo mokyklose jie neigijo pakankamai žinių apie paprasčiausius fizinio krūvio dydžio bei intensyvumo fiziologinius rodiklius, jų matavimą ir kontrolę. Dèl šios priežasties studentai negali fizinès sveikatos gerinimo tikslu saugiai savarankiškai mankštintis laisvalaikiu. Studentų informuotumą apie paprasčiausius fiziologinius rodiklius ir jų matavimą lemia studijų kryptis.

3. Pusė aukštujų mokyklu pirmakursių turi tvirtą nuostata, kad fizinès sveikatos gerinimo proceso sèkmè priklauso nuo asmeninès iniciatyvos. Tie studentai, kurie kontroliuoja pulsą ir kraujospūdi, lankosi pas gydytojus $1-2$ kartus per metus, rūpinasi sveikata ir teigia, kad ji gera, fizini aktyvumą vertiną kaip vieną pagrindinių sveikatinimo priemonių.

\section{LITERATŪRA}

Armonienė, J. (1994). Kūno kultūra ir studenčių sveikata. Kūno kultūros problemos Lietuvos aukštojoje mokykloje. Kaunas: Ritmas. P. 18.

Astrauskienė, A., Jansonienè, A., Šapokienè, L. (2005). KTU ir KMU pirmo kurso studenčiu požiūris ì sveikatą kaip gyvenimiškają vertybę. Kultūra. Ugdymas. Visuomené: mokslo darbai, 1, 315-317.

Astrom, A. N., Rise, J. (2001). Socio-economic differences in patterns of health and oral health behavior in 25 year old Norwegians. Clinical Oral Investingation, 5 (2), $122-128$.

Buliuolis, A., Trinkūnas, E., Snarskaitè, R., Poderys, J. (2003). Didelio meistriškumo sportininkų ir nesportuojančių asmenų širdies ir kraujagyslių sistemos funkcinės būklès kaita, atliekant aerobinius ir anaerobinius krūvius. Sporto mokslas, 1, 56-61.

Goštautas, A., Šeibokaitė, L. (2003). Moksleivių narkotinių medžiagų vartojimo, priklausančio nuo savo sveikatos vertinimo, kitimas amžiaus tarpsniais. Socialinis darbas, 2 (4), 103-110.

Grabauskas, V., Klumbienė, J., Petkevičienè, J. ir kt. (1997). Suaugusiu Lietuvos žmoniu gyvensenos tyrimas, 1994. Helsinkis: Nacionalinis visuomenès sveikatos institutas.

Grabauskas, V., Klumbienė, J., Petkevičienė, J. ir kt. (2005). Suaugusiu Lietuvos žmoniu gyvensenos tyrimas, 2004. Helsinkis: Nacionalinis visuomenès sveikatos institutas.
Grinienè, E. (2005). Studentu socialinè integracija ir sveikata. Kultūra. Ugdymas. Visuomenè: mokslo darbai, 1, 326-328.

Jègeris, G. (1987). Vanduo daro stebuklus. Vilnius: Mokslas.

Juškelienė, V., Poškuvienė, R., Armonienė, J. ir kt. (2003). Studentu ir moksleivių socialiniai ir higieniniai fizinio aktyvumo aspektai. Dvasinès vertybès žiniu visuomenëje: mokslo darbai. 407-411.

Muliarčikas, A. (2003). Kauno studentų laisvalaikio fizinis aktyvumas ir ji lemiantys faktoriai. Ugdymas. Kūno kultūra. Sportas, 5 (50), 44-51.

Petkevičienè, J., Kardelis, K., Misevičienè, I., Petrauskas, D. (2002). Kauno aukštujų mokyklų studentų fizinio aktyvumo, žalingu ipročių ir studiju krypties sąsaja. Ugdymas. Kūno kultūra. Sportas, 4 (45), 77-84.

Petrauskas, D. (2004). Kauno universitety studentu subjektyvios sveikatos, savijautos ir gyvensenos sqsaju vertinimas: daktaro disertacija. Kaunas.

Poderys, J. (2000). Asmens sveikatos ugdymas. Kaunas: Kauno medicinos universitetas.

Skernevičius, J., Raslanas, A., Dadelienè, R. (2004). Sporto mokslo metodologija. Vilnius: Lietuvos sporto informacijos centras.

Soldz, S., Kreiner, P., Clark, T. W., Krakow, M. (2000). Tobacco use among Massachusetts youth: Is tobacco control working? Preventive Medicine, 31, 287-295. 
Stepaitienė, A. (1999). Alternatyvi sveikatos priežiūra. Vilnius: Rosma.

Tamošauskas, P. (2004). Fizinès saviugdos poreikio formavimo prielaidos. Tiltai. Priedas: mokslo darbai. Kūno kultūros ir sveikatos ugdymo šiuolaikinés problemos, 23, 14-22.

Tamošauskas, P. (2000). Humanistiškai orientuotas studentu fizinis ugdymas. Vilnius: Technika.

Tavelli, S., Beerman, K., Shultz, J. E., Heiss, C. (1998). Sources of error and nutrition adequacy of the food guide pyramid. Journal of American College Health, 47 (2), 77-82. Varatinskienè, R. (1993). Kauno aukštuju mokyklu studentu gyvensenos ypatybès ir sveikata: medicinos mokslu daktaro disertacija. Kaunas: Kauno medicinos akademija.

Vasiliauskas, A. (2002). Strateginis valdymas. Vilnius: Enciklopedija.
Vaščila, V., Gargasas, S., Vyskupaitis, E. ir kt. (2005). Kūno kultūros pratybų veiksmingumas pirmo kurso studentų požiūriui i kūno kultūrą. Ugdymas. Visuomené: mokslo darbai, 1, 385-387.

Vaščila, V. (2003). Lietuvos žemès ūkio universiteto pirmo kurso studentu sveikatos savianalizè. Dvasinès vertybès žiniu visuomenèje: mokslo darbai, 265-267.

Zaborskis, A., Makari, J. (2001). Lietuvos moksleiviu gyvensena: raida 1994-1998 metais ir vertinimas tarptautiniu požiūriu. Panevėžys: E. Vaičekausko leidykla.

Баевский, Р. М. (1986). Ритм сердияа у спортсменов. Москва: Физкультура и спорт.

Тхоревский, В. И. (2001). Физиология человека. Москва: Физкультура, образование и наука.

\title{
ANALYSIS OF LINKS BETWEEN PHYSICAL HEALTH PRESERVATION, HEART RATE, BLOOD PRESSURE AND PHYSICAL ACTIVITY IN LEISURE OF STUDENTS OF KAUNAS UNIVERSITIES
}

\author{
Algirdas Muliarčikas ${ }^{1}$, Robertas Veršinskas ${ }^{1}$, Aleksas Stanislovaitis ${ }^{2}$ \\ Mykolas Romeris University ${ }^{1}$, Lithuanian Academy of Physical Education ${ }^{2}$, Kaunas, Lithuania
}

\begin{abstract}
The aim of the paper was to establish links between physical health evaluation and improvement, heart rate and blood pressure control, the choice of the most popular means of health improvement during in the leisure time. The data of questionnaires filled in by $1^{\text {st }}$-year students of Kaunas university - type schools are presented in the paper. The data reflect the students knowledge of their subjective attitude to their health condition, as well as means of controlling and managing it. First-year students ( $=992)$ of six Kaunas university - type schools, i.e. Kaunas Technological University (KTU), Kaunas University of Medicine (KUM), Vytautas Magnus University (VMU), Lithuanian Veterinary Academy (LVA), Lithuanian University of Agriculture (LUA) and Mykolas Romeris University (MRU), filled in anonymous questionnaires. Pilot study was carried out and the validity of questionnaire was established.

The majority of the students questioned take care of their health (85\%). The greater part of the respondents (52\%) estimated their health condition subjectively as „satisfactory“ and the small part — as good ( $\mathrm{p}<0.01)$ accordingly. Of all respondents the smallest part of students who estimated their health as „good“ ( $<<0.05)$ were of KTU and LUA. 1-st year students of KTU visited doctors most frequently, whereas the rarest patients of KUM, LUA and MRU ( $<<0.05)$. Over two thirds of the respondents (70\%) did not count their pulse and over half of them did not know their pulse readings in the state of rest. $27 \%$ of $1^{\text {st }}$-year students had no idea of importance of knowing their blood pressure. Of those who did not know their blood pressure indices the greatest part was made up of LUA students and the smallest - of KMU students ( $\mathrm{p}<0.01)$. The majority of the respondents were of the opinion that adequate physical load was one of the more important means of decreasing overweight and strengthening health $(\mathrm{p}<0.05)$. The students distinguished three important means generating liveliness throughout the day, i.e. morning coffee, cold shower and doing morning exercises $(\mathrm{p}<0.05)$. Students of Kaunas university - types schools have formed positive understanding of the basic means of improving physical health. Still a comparatively small portion of the respondents possesses information about the most elementary means of controlling human health condition and managing the process of physical activity.
\end{abstract}

Keywords: physical health, knowledge about physical indices, body condition control, process of physical activity in leisure time.

Gauta 2006 m. vasario 7 d.

Received on February 7, 2006

Priimta 2006 m. gegužès 25 d.

Accepted on May 25, 2006
Algirdas Muliarčikas

Mykolo Romerio universitetas

(Mykolas Romeris University)

V. Putvinskio g. 70, LT-44211 Kaunas

Lietuva (Lithuania)

Tel +370 37303653

E-mail a.muliarcikas@ltukf.lt 